\title{
Targeting metabolism with arsenic trioxide and dichloroacetate in breast cancer cells
}

\author{
Ramon C Sun ${ }^{1,2}$, Philip G Board ${ }^{1}$ and Anneke C Blackburn ${ }^{1 *}$
}

\begin{abstract}
Background: Cancer cells have a different metabolic profile compared to normal cells. The Warburg effect (increased aerobic glycolysis) and glutaminolysis (increased mitochondrial activity from glutamine catabolism) are well known hallmarks of cancer and are accompanied by increased lactate production, hyperpolarized mitochondrial membrane and increased production of reactive oxygen species.

Methods: In this study we target the Warburg effect with dichloroacetate (DCA) and the increased mitochondrial activity of glutaminolysis with arsenic trioxide (ATO) in breast cancer cells, measuring cell proliferation, cell death and mitochondrial characteristics.

Results: The combination of DCA and ATO was more effective at inhibiting cell proliferation and inducing cell death than either drug alone. We examined the effect of these treatments on mitochondrial membrane potential, reactive oxygen species production and ATP levels and have identified new molecular mechanisms within the mitochondria for both ATO and DCA: ATO reduces mitochondrial function through the inhibition of cytochrome $C$ oxidase (complex IV of the electron transport chain) while DCA up-regulates ATP synthase $\beta$ subunit expression. The potentiation of ATO cytotoxicity by DCA is correlated with strong suppression of the expression of c-Myc and $\mathrm{HIF-1} \alpha$, and decreased expression of the survival protein BCl-2.
\end{abstract}

Conclusion: This study is the first to demonstrate that targeting two key metabolic hallmarks of cancer is an effective anti-cancer strategy with therapeutic potential.

Keywords: Dichloroacetate, breast cancer, electron transport chain, mitochondria, arsenic trioxide

\section{Introduction}

Arsenic trioxide (ATO) has been used as a therapeutic agent for over 2000 years. Originating from China [1], it is currently being used against acute promyeloid leukemia (APL) in patients who have relapsed following alltrans-retinoic acid/anthracycline therapy and is being promoted for first line therapy of de novo APL [2-4]. ATO is known as a hyper-reactive molecule and could potentially bind to thiol groups in many proteins [2,5]. Its ability to bind to the thiol-rich, mutant protein PML-RAR- $\alpha$ produced from a chromosome translocation in APL has made it an effective drug in APL $[2,5,6]$. ATO has been shown to induce apoptosis in a variety of cancer cell lines in vitro and in vivo $[7,8]$, but

\footnotetext{
* Correspondence: Anneke.Blackburn@anu.edu.au

'Molecular Genetics Group, Department of Translational Biosciences, John Curtin School of Medical Research, Building 131, Australian National University, P.O. Box 334, Canberra ACT 0200, AUSTRALIA Full list of author information is available at the end of the article
}

it has been difficult to consider ATO for clinical use in tumor types other than APL due to the lack of knowledge of the molecular targets that result in its cytotoxicity. In the past 10 years, physiological changes within cancer cells in response to ATO treatment have been well characterized, and many clinical trials for new applications of ATO are underway [5]. ATO has been proposed as a mitochondrial toxin [9]. ATO can depolarise the mitochondrial membrane potential (MMP) [10], increase intracellular reactive oxygen species (ROS) production [8], and induce apoptosis [8]. The proposed target for ATO that can achieve these phenotypic changes is the mitochondrial transition pore (MTP) [11]. ATO has been shown to induce the opening of the MTP, which induces cytochrome c release and is proposed to dissipate the MMP and increase ROS release from the mitochondria [12]. More recently, the thioredoxin system, in particular thioredoxin reductase, has

\section{Biomed Central}

(c) 2011 Sun et al; licensee BioMed Central Ltd. This is an Open Access article distributed under the terms of the Creative Commons Attribution License (http://creativecommons.org/licenses/by/2.0), which permits unrestricted use, distribution, and reproduction in any medium, provided the original work is properly cited. 
also been identified as a target of ATO that may contribute to increased oxidative stress and altered redox signalling after ATO treatment of cancer cells $[9,13]$.

The Warburg effect is a wide spread phenomenon that has been identified in over $90 \%$ of all tumor forms. Cells that exhibit the Warburg effect take on alternative routes of energy homeostasis to maintain their proliferative phenotype [14]. Nobel laureate Dr Otto Warburg stated that cancer cells rely on glycolysis or substrate phosphorylation to generate ATP, and suppress their mitochondrial activities [15]. With more advanced technologies, recent studies have confirmed the ATP production aspect of the Warburg hypothesis but revealed that mitochondrial activity is not suppressed in cancer cells. Instead mitochondria play vital roles in providing substrates to maintain cell division [16].

The anti-cancer effect of reversing the Warburg effect has been described recently and an old drug dichloroacetate (DCA), which can redirect ATP synthesis from glycolysis to oxidative phosphorylation, has demonstrated good anti-cancer activity both in vitro [17-19] and in vivo [20-23]. DCA is a pyruvate dehydrogenase kinase inhibitor, and results in increased pyruvate dehydrogenase activity [19]. This leads to the increased conversion of pyruvate to acetyl-CoA rather than lactic acid as described by the Warburg effect, and stimulates mitochondrial respiration by increasing the supply of acetyl-CoA. Consequently, after DCA treatment, cancer cells showed increased levels of ROS, depolarization of the MMP in vitro and increased apoptosis both in vitro and in vivo $[17,20]$.

As DCA can redirect substrates into mitochondrial respiration and ATP production, it could have a synergistic activity with anti-cancer drugs that impair mitochondrial activity. We propose that by reversing the glycolytic phenotype with DCA and directing more pyruvate into mitochondrial oxidative phosphorylation, while simultaneously targeting the mitochondria with ATO, a severe disruption of energy homeostasis will occur within cancer cells. In this study we show that in combination DCA and ATO work together to inhibit the growth of breast cancer cell lines in vitro. Further, we have identified new molecular mechanisms within the mitochondria that can contribute to the cytotoxicity of ATO providing additional support for the use of ATO against solid tumours.

\section{Materials and methods Reagents}

JC-1, CFSE and $\mathrm{H}_{2}$ DCFDA were from Invitrogen (Carlsbad, CA, USA), CellTiter-Glo and Caspase-Glo assay kits were purchased from Promega Co (San Luis, CA, USA). The rest of the chemicals were purchased from Sigma Co (St. Louis, MO, USA).

\section{Cell culture}

Cell lines were obtained from the following sources in the years indicated. Dr Anna DeFazio, Westmead Millenium Institute, Sydney, Australia: T-47D (2003), BT-20 (2003), MCF-10A (2005) and MCF-10AT1 (2005); Prof Chris Parish, Australian National University, Canberra, Australia: 13762 MAT (2007), MDA-MB-468 (2003) and MDA-MB-231 (2003). The cell lines have appearances consistent with published morphologies, but have not been authenticated recently. Human breast epithelial carcinoma cells (T-47D) were grown in RPMI 1640 medium supplemented with $10 \%$ fetal bovine serum in the presence of $0.1 \%$ PSN (3\% penicillin, $5 \%$ streptomycin and $5 \%$ neomycin). BT-20, MDA-MB-231, MDA-MB-468, and 13762 MAT cell lines were maintained in DMEM/F12 medium supplemented with $10 \%$ FBS and $2 \mathrm{mM}$ L-glutamine. DMEM/F-12 medium with $25 \%$ horse serum, $0.01 \% \mathrm{EGF}, 0.28 \mathrm{IU} / \mathrm{ml}$ insulin, $0.01 \%$ cholera toxin and $0.5 \mu \mathrm{g} / \mathrm{ml}$ hydrocortisone used for MCF-10A and MCF-10AT1 cells. All of the cell lines were maintained at $37^{\circ} \mathrm{C}$ in $5 \% \mathrm{CO}_{2}$.

\section{Cell viability}

For the assessment of cell viability, cells were plated in 96 well plates at a density of 3000 cells per well and 8 wells per group. Following exposure to DCA and ATO for 24 to 72 hours, cells were incubated for 3 hours with neutral red $(30 \mu \mathrm{g} / \mathrm{ml})$ in fresh media, then washed with PBS, followed by the addition of lysis buffer (acetic acid/methanol, $80 \% / 20 \%)$ and the absorbance at $540 \mathrm{~nm}$ was recorded. Results are expressed as mean \pm S.D, calculations were performed using the Prism software package, ANOVA with Tukey post test was applied and $\mathrm{P}<0.05$ was considered to be statistically significant. Experiments were performed at least three times and data presented are of one representative experiment.

\section{Cell proliferation}

$\mathrm{T}-47 \mathrm{D}$ cells were harvested and resuspended in $1 \mathrm{ml}$ of RPMI medium. Cells were labelled by the addition of 1 $\mathrm{ml}$ of PBS containing $5 \mu \mathrm{M}$ The carboxyfluorescein succinimidyl ester (CFSE), followed by $5 \mathrm{~min}$ incubation at room temperature. Labelled cells were then washed twice, counted and seeded at $10^{5}$ cells/well in a 12 well plate. On the day of analysis, T-47D cells were harvested and washed twice with PBS and then CFSE intensity was examined by FACS. Results are expressed as mean \pm S.D $(n=3)$, calculations were performed using the Prism software package, ANOVA with Tukey post test was applied and $\mathrm{P}<0.05$ was considered to be statistically significant. Experiments were performed at least three times and data presented are of one representative experiment. 


\section{Cell death}

Apoptosis was quantitated by flow cytometry after staining cells with FITC-labelled Annexin-V (AV) (Invitrogen Co.) and propidium iodide (PI). After drug treatment, T-47D cells were harvested and centrifuged at $1200 \mathrm{rpm}$ for 5 min; the pellets were washed twice with PBS and then resuspend in $100 \mu \mathrm{l}$ of Annexin-V binding buffer (0.14 M $\mathrm{NaCl}, 2.5 \mathrm{mM} \mathrm{CaCl}_{2}, 0.01 \mathrm{M}$ HEPES pH 7.4). Annexin-V $(1 \mu \mathrm{L})$ and $5 \mu \mathrm{l}$ of PI $(50 \mu \mathrm{g} / \mathrm{ml})$ were added to the samples and incubated in the dark for $15 \mathrm{~min}$. Samples were kept on ice after incubation until FACS analysis was performed. Results are expressed as mean \pm S.D $(n=3)$, calculations were performed using the Prism software package, ANOVA with Tukey post test was applied and $\mathrm{P}<0.05$ was considered to be statistically significant. Experiments were performed at least three times and data presented are of one representative experiment.

\section{ROS generation}

For the assessment of intracellular ROS levels, cells were plated in 12 well plates with cell density of $1 \times 10^{5}$ cells per well and treated with drugs for 12 hours. 2', 7'-dihydrochlorofluroresceinacetate $\left(\mathrm{H}_{2} \mathrm{DCFDA}\right)$ was added to the medium at a final concentration of $10 \mu \mathrm{M}$ and the cells were allowed to stain for 1 hour in the dark. After $\mathrm{H}_{2}$ DCFDA staining, cells were trypsinized, washed twice and resuspended in $100 \mu \mathrm{l}$ of PBS. $\mathrm{H}_{2}$ DCFDA intensity was examined using FACS. Results are expressed as mean \pm S.D $(n=3)$, calculations were performed using the Prism software package, ANOVA with Tukey post test was applied and $\mathrm{P}<0.05$ was considered to be statistically significant. Experiments were performed at least three times and data presented are of one representative experiment.

\section{ATP concentration and Caspase activity}

Internal ATP level and caspase activity in T-47D cells was assessed using CellTiter-Glo and Caspase-Glo 3/7 assay kits (Promega Corp., Madison, WI) according to the manufacturer's instructions. T-47D cells were cultured in the absence and presence of drugs for 12 hours in white opaque 96 well plates (4 wells per group). Equal volumes of CellTiter-Glo reagents were added after which the samples were incubated for 15 min on a shaker at room temperature. Luminescence was recorded using the Glomax micro-plate luminometer (Promega Co., Madison, WI) under the preset CellTiter protocol. Results are expressed as mean \pm S.D $(n=4)$, calculations were performed using the Prism software package, ANOVA with Tukey post test was applied and $\mathrm{P}<0.05$ was considered to be statistically significant. Experiments were performed at least three times and data presented are of one representative experiment.

\section{Mitochondrial membrane potential}

Similarly to the measurement of ROS, cells were plated in 12 well plates with cell density of $1 \times 10^{5}$ cells per well and treated with drugs for 12 hours. 5, 5', 6, 6'-tetrachloro-1, 1', 3, 3'-tetraethylbenzimidazol-carbocyanine iodide (JC-1) was added in the medium at a final concentration of $0.2 \mu \mathrm{M}$ and the cells were allowed to stain for $30 \mathrm{~min}$ in the dark. After JC-1 staining, cells were trypsinized, washed twice with PBS and resuspended in $100 \mu \mathrm{l}$ of PBS. JC- 1 intensity was examined using FACS. Results are expressed as mean \pm S.D $(n=3)$, calculations were performed using the Prism software package, ANOVA with Tukey post test was applied and $\mathrm{P}<0.05$ was considered to be statistically significant. Experiments were performed at least three times and data presented are of one representative experiment.

\section{Cytochrome $\mathrm{C}$ oxidase activity}

Cytochrome $\mathrm{C}$ oxidase assay was assessed based on the method previously published [24]. Briefly, after drug treatment in 96 well plates ( 8 wells per group), T-47D cells were permeabilized with $50 \mu \mathrm{l}$ of $0.01 \%$ saponin, followed by the addition of $100 \mu \mathrm{l}$ substrate medium $(4 \mathrm{mM}$ 3,3-diaminobenzidine tetrahydrochloride (DAB), $100 \mu \mathrm{M}$ reduced cytochrome $C, 2 \mu \mathrm{g} / \mathrm{ml}$ catalase in $0.1 \mathrm{M} \mathrm{Na}$ phosphate, $\mathrm{pH} 7.0)$. Absorbance at $450 \mathrm{~nm}$ was measured immediately after the addition of substrate medium and monitored over $30 \mathrm{~min}$. Results are expressed as mean \pm S.D $(n=8)$, calculations were performed using the Prism software package, ANOVA with Tukey post test was applied and $\mathrm{P}<0.05$ was considered to be statistically significant. Experiments were performed at least three times and data presented are of one representative experiment.

\section{PDH activity}

PDH activity was measured using the MitoSciences PDH enzyme activity microplate assay kit (\#MSP18, MitoSciences, Oregon USA). For measuring the effect of drugs on PDH activity in cells, T-47D cells were treated with drugs in media for 3 hrs, after which they were washed and resuspended in PBS. Cell extracts were prepared and assayed for PDH activity at a concentration of $15 \mathrm{mg}$ protein $/ \mathrm{ml}$, according to the kit instructions. For measurement of direct inhibition of PDH by ATO, PDH was isolated from untreated T-47D cells by applying cell extracts to the antibody capture plate. After washing the plate, assay solution containing drug was added to the wells and then immediately assayed for activity PDH. Results are expressed as mean \pm S.D $(n=4)$, calculations were performed using the Prism software package, ANOVA with Tukey post test was applied and $\mathrm{P}<0.05$ was considered to be statistically significant. Experiments 
were performed at least three times and data presented are of one representative experiment.

\section{Immunoblotting and densitometric analysis}

Cells $\left(1 \times 10^{6}\right)$ were plated in T25 tissue culture flasks and were treated with ATO or DCA for 12 hours. Cell lysates were prepared by the addition of $500 \mu \mathrm{l}$ of the M$\mathrm{PER}^{\circledR}$ mammalian protein extraction reagent (Thermo Scientific, IL, USA). Immunoblotting was performed as described previously [25], using the antibodies for c-Myc (Roche, IN, USA, clone 9E10), HIF-1 $\alpha$ (Abcam, Cambridge, UK, \#ab82832), Bcl-2 (Abcam \#ab692), ATP synthase $\beta$-subunit (Abcam \#ab14730) and $\beta$-actin (Abcam \#ab8227). Western blots were detected using chemiluminescence and exposure of $x$-ray film. Images were acquired using a CanoScan 8600F flatbed scanner, and quantitated using the ImageJ software (version 1.4, $\mathrm{NIH}$, USA) and standardized to $\beta$-actin in each lane. Results were pooled from 3 separate experiments and expressed as mean \pm S.D $(n=3)$, calculations were performed using the Prism software package, ANOVA with Tukey post test was applied and $\mathrm{P}<0.05$ was considered to be statistically significant.

\section{Results}

DCA and ATO together are more effective at reducing cell proliferation and inducing cell death

To investigate the combined effect of ATO and DCA at inhibiting cell growth, breast cancer cell lines were treated for several days with both drugs and total cell number was assessed using the neutral red cell viability assay. The panel of cell lines represent the major subtypes of human breast cancer (luminal (T-47D), basal A (MDAMB-468, BT-20), basal B (MDA-MB-231)), or have other relevance as experimental models (13762MAT - rat mammary adenocarcinoma sensitive to DCA in vivo [22], MCF10AT1 - malignant derivative of immortalized cells MCF-10A). MDA-MB-468, MDA-MB-231, and T-47D cells all showed a significant reduction ranging from $10 \%$ to $40 \%$ in total cell number after 72 hours treatment with $5 \mathrm{mM}$ DCA (Figure 1A) while $13762 \mathrm{MAT}, \mathrm{BT}-20$ and MCF-10AT1 cells did not respond during the treatment period. All of the cancer cell lines tested were sensitive to ATO but at different concentrations. A reduction in total cell number was seen in BT-20, T-47D, MCF-10AT1 and MDA-MB-468 with only $5 \mu \mathrm{M}$ ATO treatment, however $15 \mu \mathrm{M}$ ATO was required to achieve the same efficiency in MDA-MB-231 and 13726 MAT cell lines. Strikingly, DCA and ATO in combination showed a greater effect than either drug alone in all of the cancer cell lines tested. Where ATO and DCA were effective as single agents at reducing cell numbers, the effect of combined treatment was approximately equal to the sum of the individual drug effects (T-47D, MDA-MB-468 and
MDA-MB-231). Where DCA alone showed no reduction in cell number, it was still able to enhance the growth inhibition of ATO by 2-3 fold (13762 MAT, BT-20 and MCF10AT1) (Figure 1A). The non-cancerous cell line, MCF-10A showed no reduction in cell number after ATO $(15 \mu \mathrm{M})$, DCA $(5 \mathrm{mM})$ or combined treatment.

The effect of ATO and DCA was examined further with $\mathrm{T}-47 \mathrm{D}$ cells, one of the cell lines more sensitive to DCA alone. The response of T-47D cells towards DCA was dose-dependent and after 72 hours, $5 \mathrm{mM}$ DCA treated cells had $42 \pm 6 \%$ less cells than the control culture (Figure $1 \mathrm{~B})$. ATO alone $(5 \mu \mathrm{M})$ reduced the total cell number by $56 \pm 4 \%$ and cells treated with both DCA and ATO showed a further decrease compared to the ATO only group (Figure 1C). The dose response curve showed that combination treatment of DCA $(5 \mathrm{mM})$ and ATO can reduce the $\mathrm{IC}_{50}$ to 0.25 -fold that of ATO alone (Figure $1 C)$. This effect is occurring within the concentration range achieved clinically for ATO (up to 5-7 $\mu \mathrm{M}$ [26]).

CFSE proliferation assay demonstrated that either ATO $(5 \mu \mathrm{M})$ or DCA $(5 \mathrm{mM})$ treated cells emitted significantly higher CFSE fluorescence (2.1-fold and 2.2fold respectively) after 72 hours of treatment indicating growth inhibition. Cells treated with both ATO and DCA showed a 3.4-fold increase in CFSE intensity compared to untreated cells indicating the drugs worked together at inhibiting cell proliferation (Figure 1D).

The effect of ATO and DCA on T-47D cell death was assessed using AV and PI double staining and cells were analysed using fluorescent cell sorting. DCA alone (5 mM) did not induce cell death in T-47D cells (Figure 1E), similar to the effect of DCA on 13762 MAT cells reported previously [22]. ATO $(5 \mu \mathrm{M})$ also failed to induce cell death after 12 hours of treatment, however cells treated with both $5 \mu \mathrm{M}$ ATO and $5 \mathrm{mM}$ DCA showed a small (15\%) increase in $\mathrm{AV}+/ \mathrm{PI}+$ population $(13.2 \pm 0.6 \%$ apoptotic cells compared to $11.5 \pm 1.0 \%$ for ATO/DCA vs. untreated respectively, $\mathrm{p}=0.07$ ), suggesting that $\mathrm{DCA}$ may be enhancing the apoptotic effects of ATO. At higher concentrations and with 48 hours of treatment, ATO $(20 \mu \mathrm{M})$ increased the amount of cell death by $35 \pm 8 \%(P=0.029)$ compared to the untreated culture (Figure 1E). Combining $5 \mathrm{mM}$ DCA with $20 \mu \mathrm{M}$ ATO treatment resulted in a 4-fold greater increase in the $\mathrm{AV}+/ \mathrm{PI}+$ population compared to ATO alone, indicating that DCA can potentiate the cell death induced by ATO in T-47D breast cancer cells (Figure 1E).

\section{ATO and DCA work together on depolarising the MMP but have counter effects on inducing ATP and ROS production}

Both ATO and DCA have been shown to alter mitochondrial function, depolarizing MMP and increasing ROS production [20]. Therefore these parameters along 


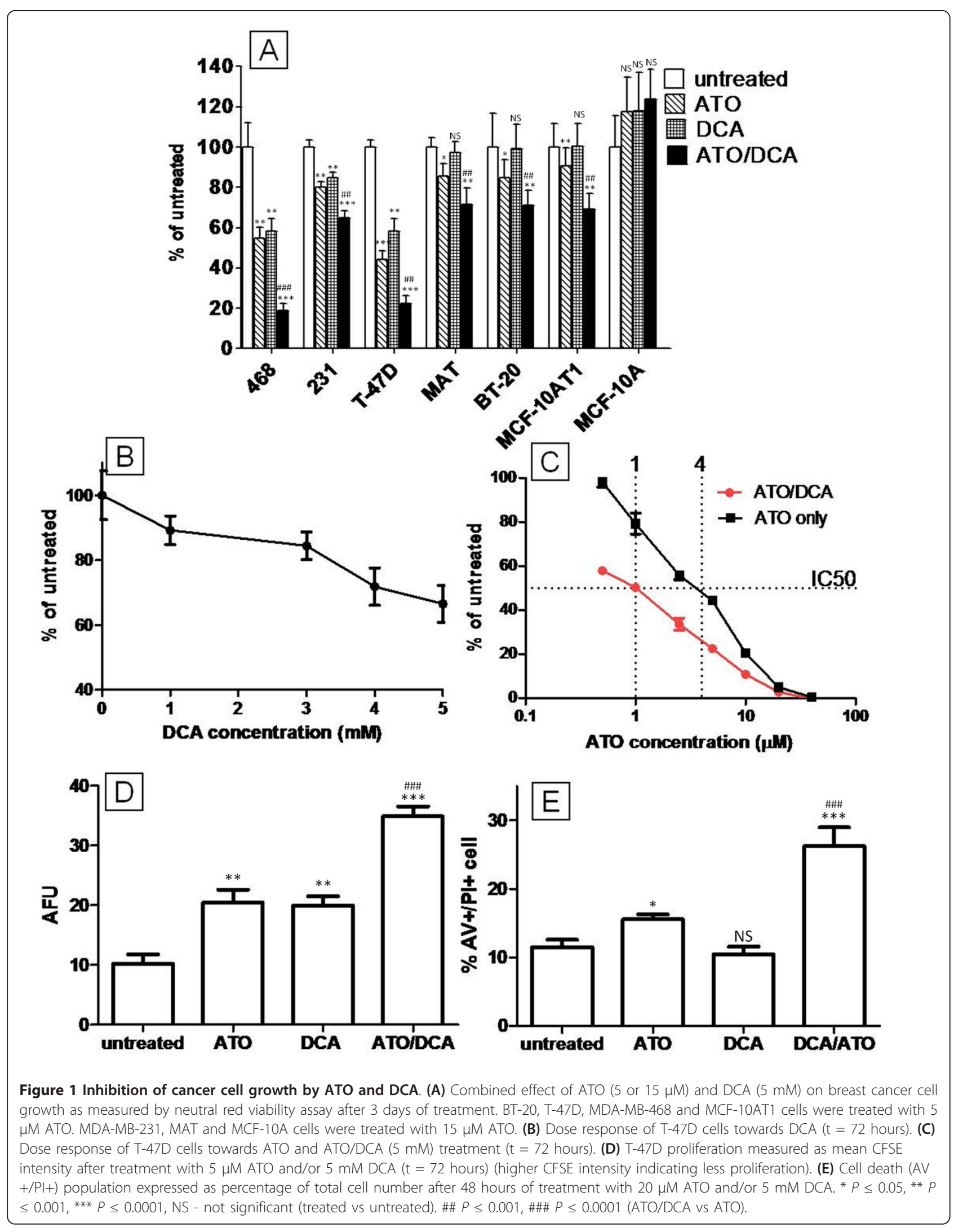


with ATP level were studied in an effort to determine whether they contribute to the enhanced anti-cancer effects of ATO/DCA combined treatment. Measured by JC-1 staining, the number of T-47D cells with a hyperpolarized MMP (upper right quadrant) was significantly decreased by DCA $(5 \mathrm{mM})$ or ATO $(5 \mu \mathrm{M}$ and $20 \mu \mathrm{M})$ treatment $(t=12$ hours $)(28 \pm 6 \%, 38 \pm 4 \%$ and $69 \pm 7 \%$ decrease respectively compared to untreated control cells), consistent with previously published data [20,27]. Combining ATO $(5 \mu \mathrm{M}$ or $20 \mu \mathrm{M})$ with $5 \mathrm{mM}$ DCA lead to an even greater decrease $(53 \pm 9 \%$ and $77 \pm 12 \%$ respectively) compared to the untreated cells (Figure 2A), demonstrating that DCA and ATO can work together in depolarizing the MMP. ATP levels were decreased by both low and high dose ATO $(14 \pm 3 \%$ and $32 \pm 5 \%$ respectively) after 12 hours of treatment, while DCA

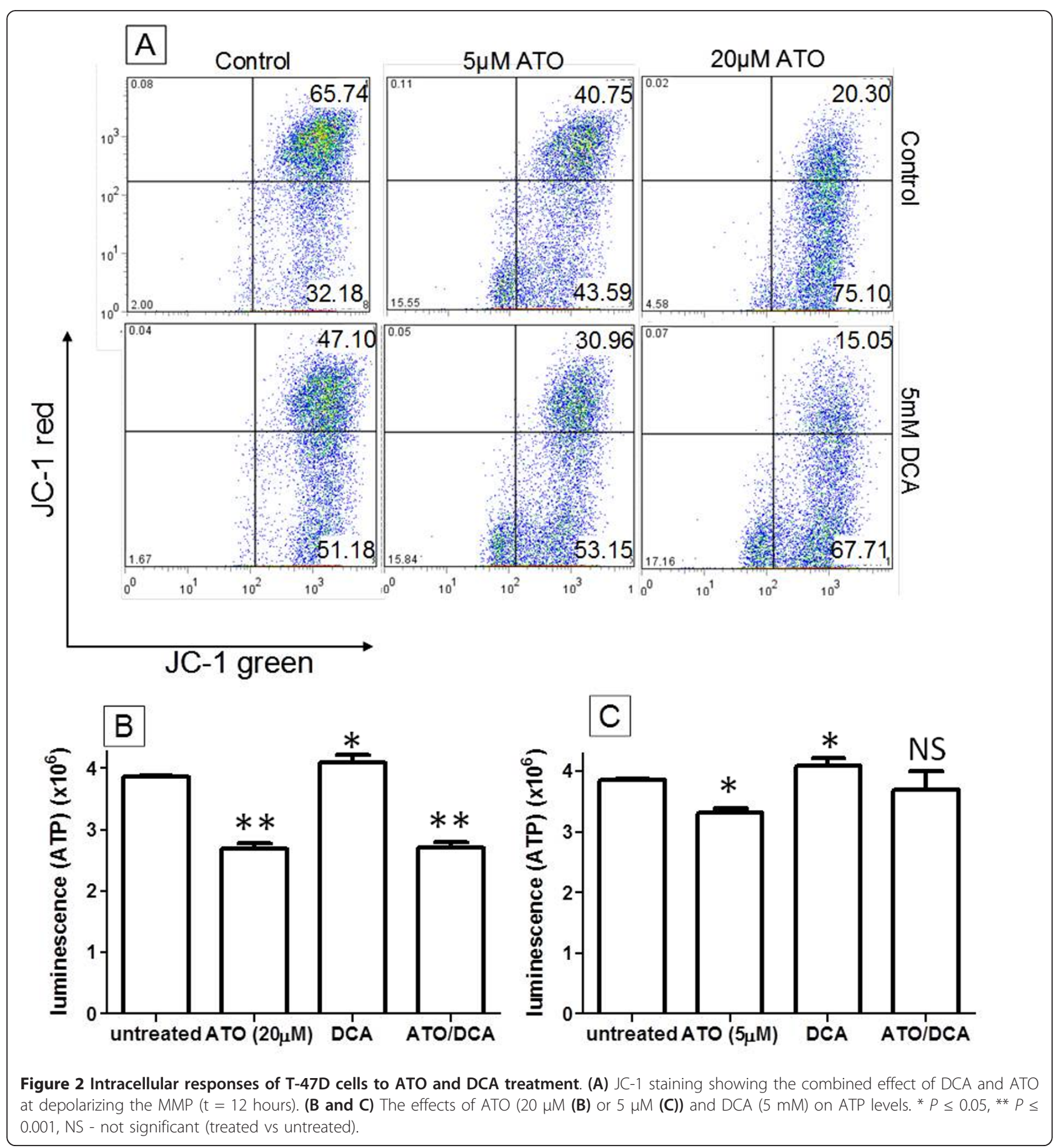


treated cells showed a $6 \pm 1 \%$ increase in ATP levels (Figure $2 \mathrm{~B}$ and $2 \mathrm{C}$ ). At the high dose of ATO, DCA was unable to increase ATP production (Figure $2 \mathrm{~B}$ ), whereas at the low dose of ATO, DCA and ATO combined treated cells showed a small increased in ATP production over ATO treatment alone (Figure 2C). This data indicates that DCA and ATO are affecting ATP production via separate targets inside the cells.

Increased intracellular ROS levels have been proposed to be the reason behind ATO cytotoxicity [2,9]. The combined effect of ATO and DCA on ROS was investigated using the fluorescent stain $\mathrm{H}_{2}$ DCFDA. Cells treated with $20 \mu \mathrm{M}$ ATO or $5 \mathrm{mM}$ DCA showed elevated intracellular ROS levels (2.8 and 1.9-fold respectively) (Figure 3A) similar to previously published results [27], while cells treated with both ATO and DCA showed a further increase (5.2fold) in ROS production.(Figure 3A). In contrast, low concentration ATO $(5 \mu \mathrm{M})$ induced a 0.5 -fold decrease in ROS production (Figure $3 \mathrm{~B}$ ). This was contrary to previous reports on ROS production and ATO treatment, so the dose-response and time course of ROS production after ATO treatment was analysed. This revealed that lower concentrations of ATO decreased intracellular ROS production while high ATO induced ROS production (Figure $3 \mathrm{C}$ ). Similarly $10 \mu \mathrm{M}$ ATO treatment resulted in a notable decrease in ROS production in the first 4 hours before ROS levels increased after 8 hours to the level reported by others (Figure 3D). Combined treatment of cells with $5 \mathrm{mM}$ DCA and $5 \mu \mathrm{M}$ ATO resulted in an intermediate ROS production (Figure 3B) similar to untreated cells.

The intermediate effects of DCA/ATO combination treatment on ATP and ROS levels may be explained by competing effects on PDH activity. DCA targets PDK, and therefore should increase PDH activity, whereas ATO has been reported to inhibit $\mathrm{PDH}$ either directly by reaction with vicinal thiols on $\mathrm{PDH}$ or indirectly via increased hydrogen peroxide production [28]. To examine the effects of ATO and/or DCA on PDH activity, intact cells or $\mathrm{PDH}$ isolated from $\mathrm{T}-47 \mathrm{D}$ cells, were treated with drug

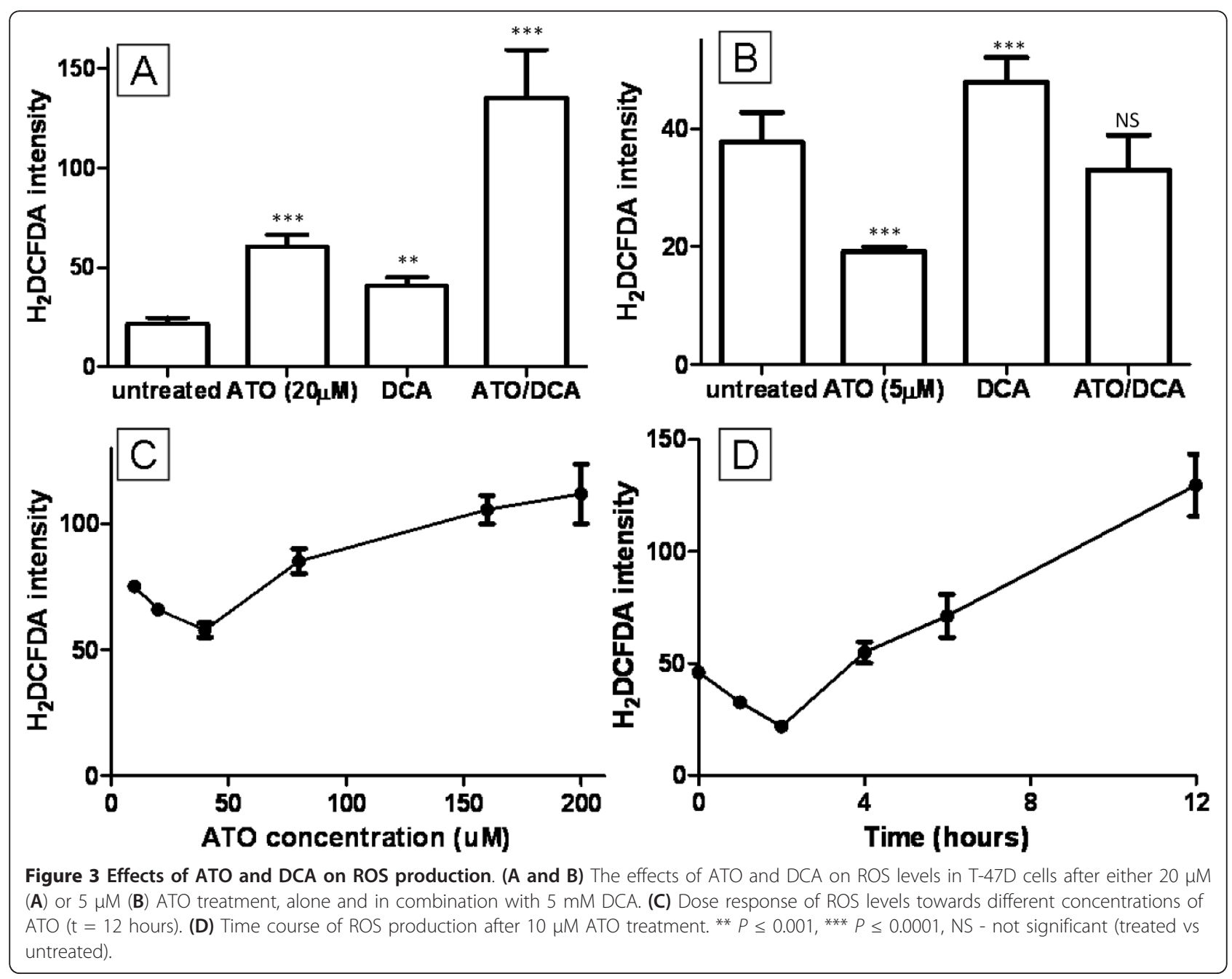


and the PDH activity determined. As predicted, $3 \mathrm{hr}$ treatment of intact cells with DCA resulted in increased PDH activity, whereas ATO (up to $20 \mu \mathrm{M}$ ) did not alter PDH activity of intact cells (Figure 4A). In contrast, DCA did not change the activity of isolated $\mathrm{PDH}$, but high concentrations of ATO were able to inhibit PDH activity (Figure 4b). Thus in T-47D cells, ATO did not decrease PDH activity at the concentrations used in this study.

\section{ATO is an inhibitor of complex IV of the electron transport chain}

The electron transport chain (ETC) is located in the inner membrane of the mitochondria and plays a vital role in energy production. The ETC is responsible for generating the proton gradient for the inner membrane space of mitochondria to maintain the MMP for ATP production [29]. The ETC is also documented as the major site of ROS production within cells as a result of electron leakage from complex I and III [30]. Due to its ability to lower ROS, depolarize MMP and decrease ATP production simultaneously, we have hypothesised that ATO operates as an ETC inhibitor. A panel of ETC inhibitors was compared to ATO $(5 \mu \mathrm{M})$ to identify whether they induce the same phenotypic changes as ATO in T-47D cells. Rotenone $(0.1 \mu \mathrm{M}$, complex I), thenolytrifluoroacetone (TTFA) $(10 \mu \mathrm{M}$, complex II), antimycin $(0.1 \mu \mathrm{M}$, complex III) and $\mathrm{NaCN}$ (10 mM, complex IV) were used to treat T-47D cells and ROS, MMP and ATP levels were compared to ATO treated cells. All of the inhibitors demonstrated abilities to depolarize MMP (Figure 5A) and reduce ATP levels
(Figure 5B) similarly to ATO. However, in contrast to ATO, rotenone, antimycin and TTFA failed to reduce ROS production within cells, instead elevating ROS 3to 6-fold after 12 hours treatment (Figure 5C). Cells treated with $\mathrm{NaCN}(10 \mathrm{mM})$ however, showed a $52 \%$ decrease in ROS production (Figure $5 \mathrm{C}$ ) similar to ATO treatment. Based on these data we concluded that in $\mathrm{T}$ 47D breast cancer cells, the inhibition of complex IV of the ETC but not complexes I-III results in a reduction of ROS, and therefore it is likely that phenotypic changes induced by ATO are caused by the inhibition of complex IV (cytochrome C oxidase) of the ETC. To confirm this, cytochrome $\mathrm{C}$ oxidase activity in T-47D cells was measured spectrophotometrically. Cytochrome C oxidase assay clearly demonstrated that while DCA had no effect on complex IV activity, ATO $(5 \mu \mathrm{M}, 5$ min) can inhibit complex IV activity confirming our hypothesis (Figure 5D). Similar results were obtained after $10 \mathrm{~min}, 3 \mathrm{hr}$ and $12 \mathrm{hr}$ drug treatments. The combination of ATO and DCA showed similar enzyme inhibition to ATO alone.

\section{Mitochondrial transition pore inhibitors partially blocked ATO induced caspase activation but had no effect on ROS, ATP and MMP}

One mechanism that has previously been described as the key to ATO cytotoxicity is the opening of the mitochondrial transition pore (MTP). ATO has been shown to induce the opening of the MTP in isolated mitochondria and can increase cytochrome $C$ release [11] and induce nuclear apoptosis in cell free systems [31]. The

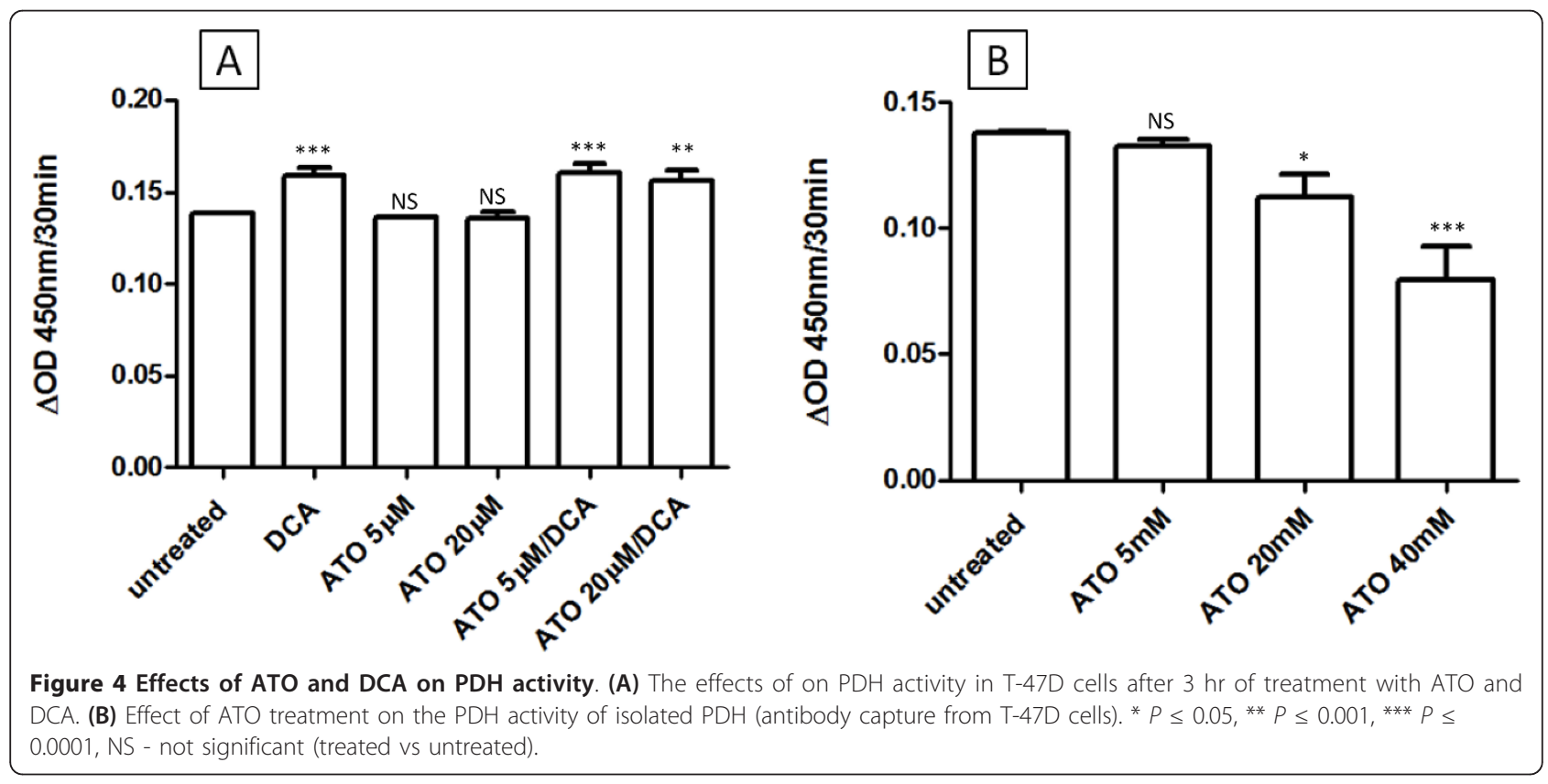




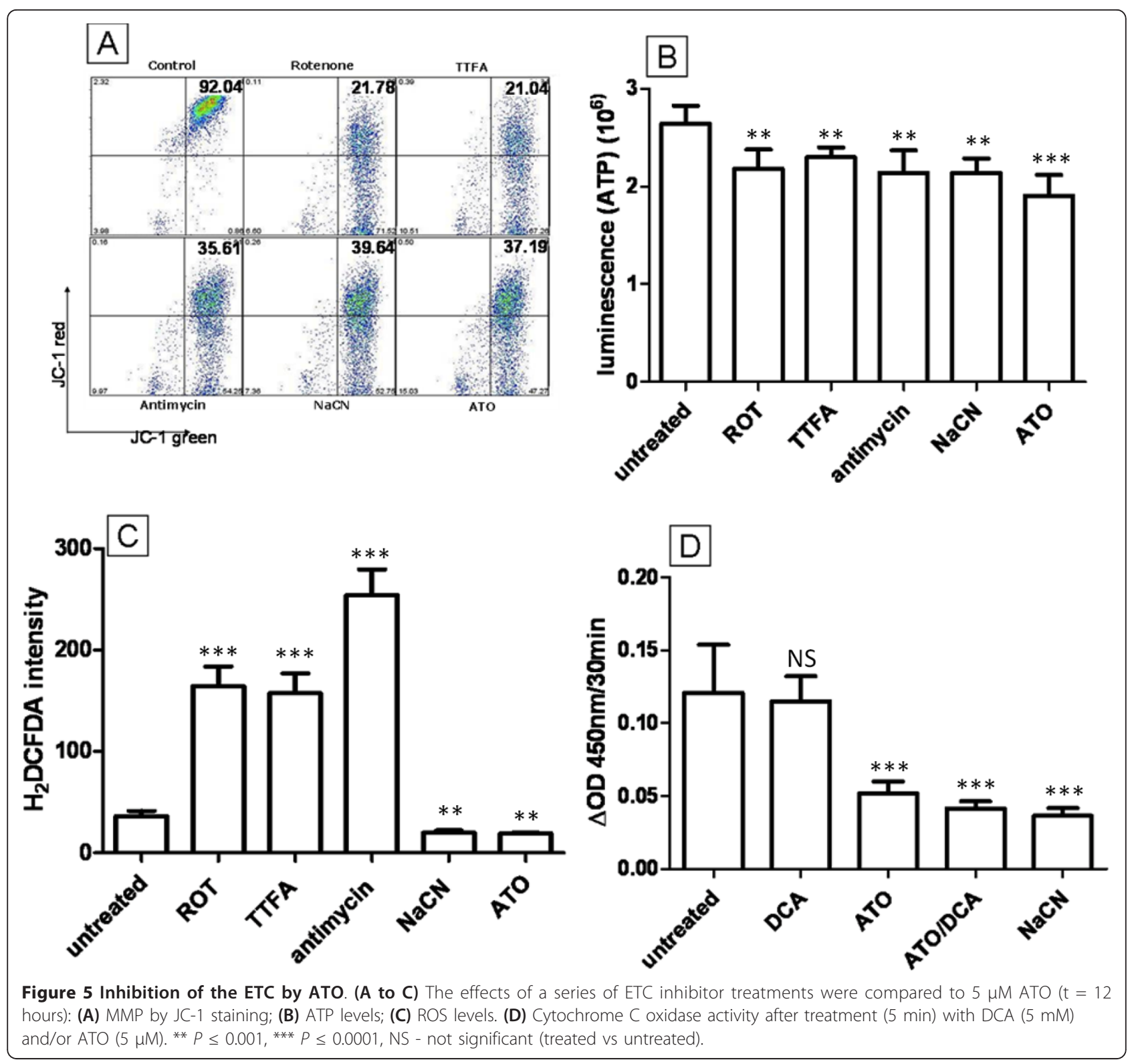

opening of MTP by ATO has been proposed to induce mitochondrial permeabilization, dissipate the MMP and increase intracellular ROS. To test whether the MTP is important for ATO toxicity in T-47D cells, bongkrekic acid (BA) and cyclosporine A (CsA), both potent MTP pore blockers [32], were combined with ATO to see whether they can inhibit ATO induced intracellular changes. The addition of $5 \mu \mathrm{M}$ CsA or $50 \mu \mathrm{M}$ BA to ATO $(5 \mu \mathrm{M})$ treated cells did not interfere with the ability of ATO to lower ROS production after 12 hours of treatment, decrease ATP production or depolarise the MMP $(P>0.05)$ (Figure 6B, C and 6D). Similar data can be seen for $\mathrm{NaCN}$ and $\mathrm{CsA} / \mathrm{BA}$ treatment $(P>0.05)$ (Figure 6B, C and 6D). To confirm the activity of CsA and BA in our experimental conditions, caspase $3 / 7$ activity, an apoptosis marker downstream of MTP opening, activated by cytochrome $\mathrm{C}$ release, was assessed after high concentration ATO treatment (Figure 6A). ATO treatment $(20 \mu \mathrm{M})$ doubled caspase $3 / 7$ activity compared to untreated cells (2.1-fold, Figure 6A) and this effect was decreased by BA and CsA (1.7-fold and 1.4-fold, respectively), indicating that CsA or BA can block MTP opening in T-47D cells. These data clearly demonstrate that although ATO $(20 \mu \mathrm{M})$ can induce the opening of MTP, this mechanism cannot explain the ROS, MMP and ATP changes occurring during $5 \mu \mathrm{M}$ ATO treatment. We conclude that these alterations are likely due to the inhibition of ETC complex IV. 


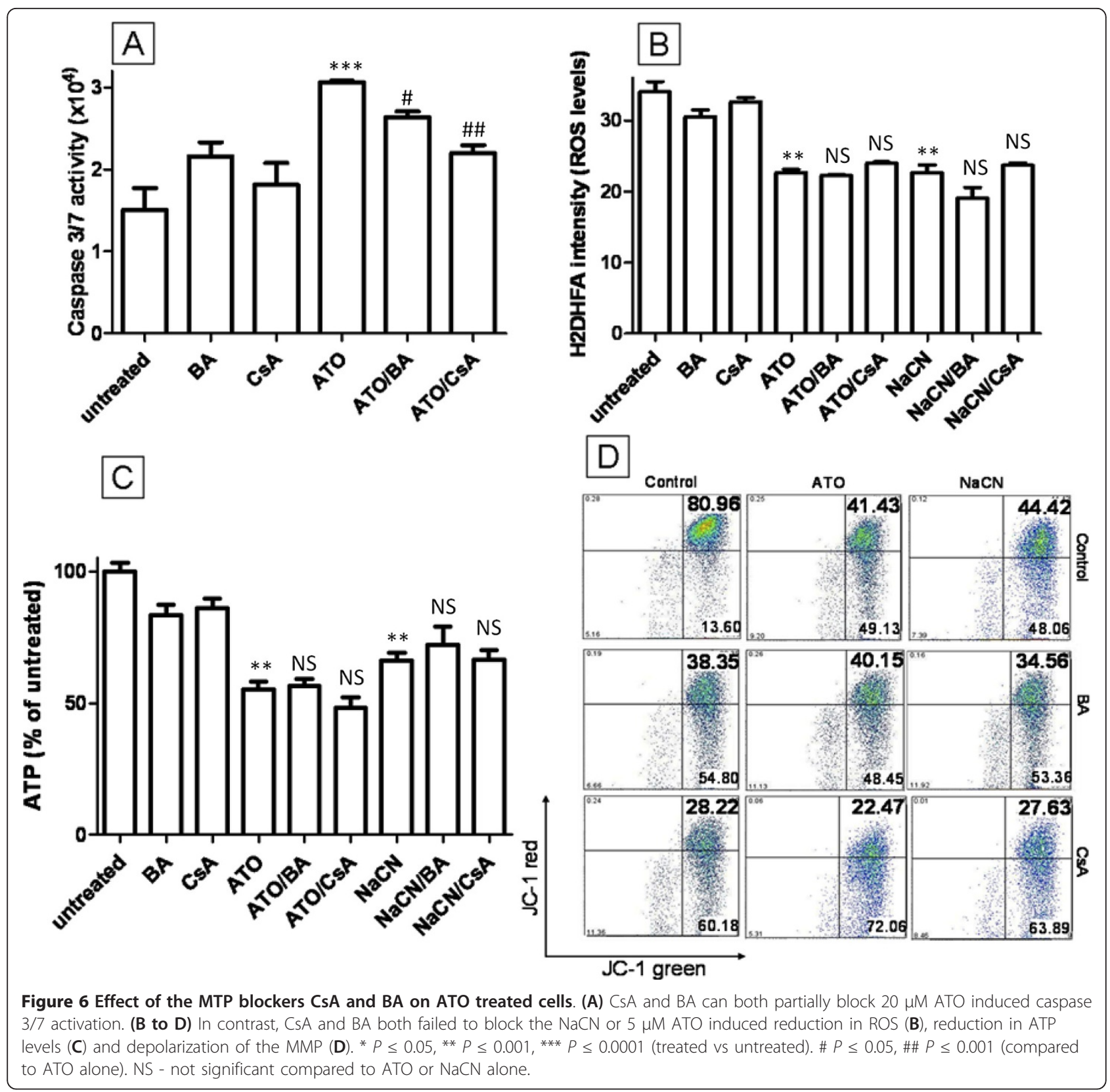

DCA and ATO have opposing effects on ATP synthase $\beta$ subunit and $\mathrm{BCl}-2$ expression while working cooperatively at down-regulating c-Myc and HIF-1 $\alpha$ protein levels

We examined the effect of $5 \mathrm{mM}$ DCA and $5 \mu \mathrm{M}$ ATO treatment (12 hours) on the expression c-Myc and HIF$1 \alpha$, two major transcription factors that are known to regulate the Warburg effect [33] and mitochondrial activity [34], and on the expression of the mitochondrial proteins ATP synthase $\beta$ subunit (ATP $\beta$ ) and Bcl-2. Immunoblotting for $\mathrm{c}-\mathrm{Myc}$ showed no change after treatment with DCA while ATO induced the up-regulation of
c-Myc (Figure 7A and 7B), however ATO in combination with DCA reduced $\mathrm{C}-\mathrm{Myc}$ level compared to the untreated control. HIF-1 $\alpha$ levels on the other hand showed a down regulation after both DCA and ATO treatment. The combination of ATO and DCA showed further down-regulation of HIF-1 $\alpha$ compared to single agent treated and control groups (Figure 7A and 7C). $\mathrm{Bcl}-2$ is a member of the $\mathrm{BH} 3$ protein family that binds directly to Bad and Bax and prevents apoptosis [35]. Immunoblotting performed for ATP $\beta$ found that DCA treatment up-regulated ATP $\beta$ while ATO showed an opposite effect, lowering ATP $\beta$ levels (Figure 7A 


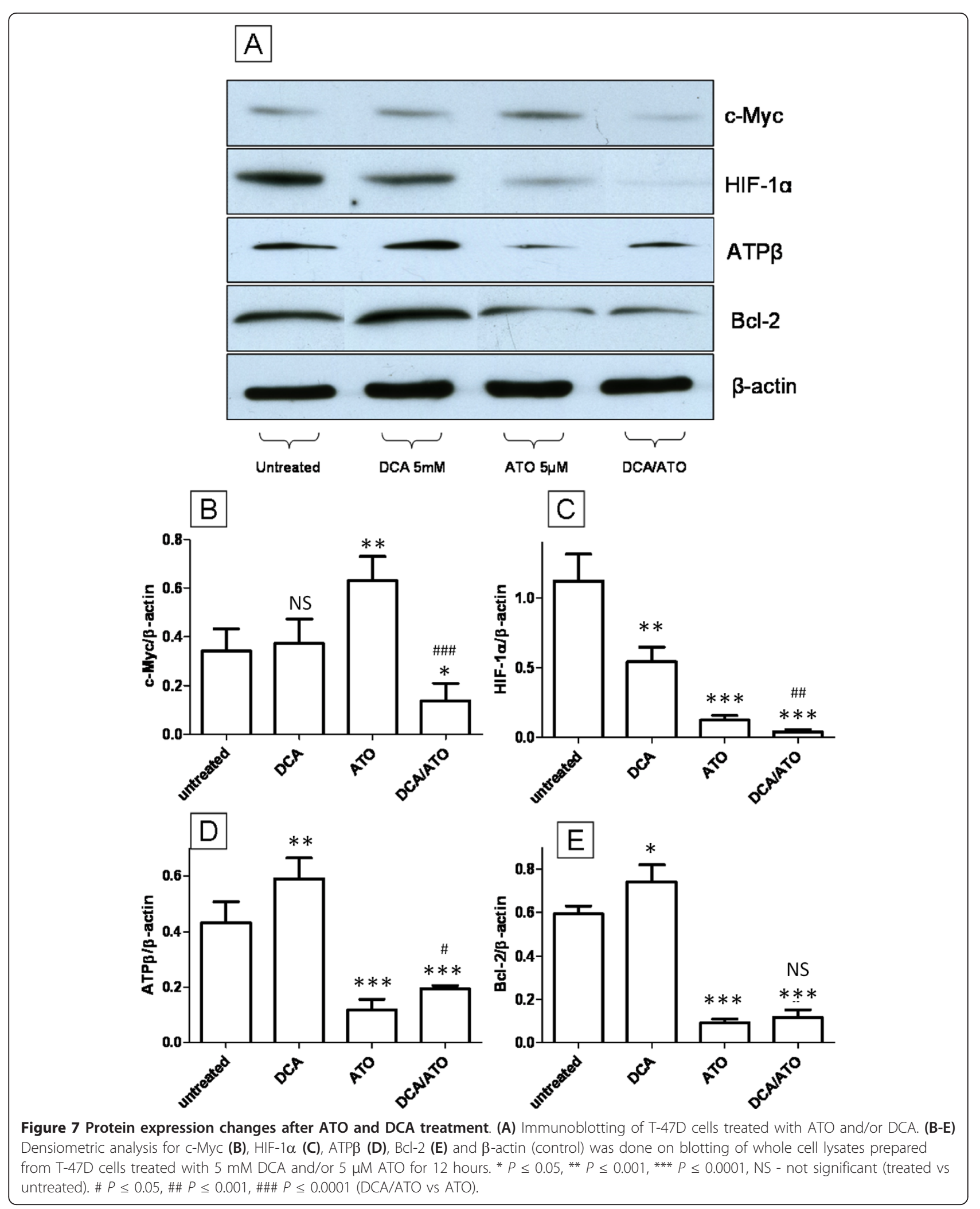


and 7D), and ATO and DCA combined treatment showed an intermediate response compared to ATO or DCA treated groups. Immunoblotting for the pro-survival protein Bcl-2 showed an up-regulation after DCA, down-regulation for ATO treatment, and an intermediate response from the combination of the two drugs (Figure 7A and 7E). These results are also very similar to ATP levels and ROS production where DCA and ATO had opposing effects (Figure $2 \mathrm{C}$ and $3 \mathrm{~B}$ ). The Bcl-2 and ATP $\beta$ results directly correlate with DCA and ATO's ability to influence ROS production and ATP levels.

\section{Discussion}

During the last decade, ATO has been used effectively to treat both newly diagnosed and relapsed APL patients, with patients showing complete remission after low dose ATO treatment [4]. The anti-cancer ability of ATO is not limited to APL [36] and many other tumors in animal models have been shown to be sensitive to ATO treatment $[37,38]$. However, the lack of information on sites of action for ATO cytotoxicity in tumor types other than APL has limited its uptake for the treatment of other cancers until recent years [5].

In this study, we have demonstrated that complex IV of the ETC is a target for ATO. From a panel of ETC inhibitors, the decrease in ROS, decrease in ATP production and MMP depolarisation caused by low dose ATO treatment of T-47D cells was reproduced only by cyanide, a well characterised complex IV inhibitor (Figure 5). Direct measurement of cytochrome $\mathrm{C}$ oxidase activity in whole cells treated with ATO confirmed the ability of ATO to inhibit this enzyme activity directly. The cytochrome $\mathrm{C}$ oxidase complex of the ETC is known to have closely spaced cysteine residues [39], and these are likely to react with ATO.

Most cancer cells have up regulated ROS levels compared to normal cells [40] and the ETC is considered the major source of intracellular ROS. The reduction in ROS of up to $60 \%$ by $\mathrm{NaCN}$ or ATO, demonstrated that complex IV is responsible for the majority of ROS production in T-47D cells. The oxidative stress of elevated ROS production has been described as a double edged sword. A moderate increase in ROS has been shown to be associated with increased proliferative potential [41], increased antioxidant enzymes such as glutathione transferase [42], superoxide dismutase and catalase [43] and increased prosurvival proteins such as Bcl-2 [42] and survivin [44]. However, intolerable amounts of ROS eventually leads to cell death [45]. The reduction in ROS after 12 hours treatment of $5 \mu \mathrm{M}$ ATO also directly correlated with a decrease in Bcl-2 levels (Figure 7E) suggesting that T-47D cells are in an apoptotic resistant state due to elevated ROS levels. Continued inhibition of complex IV of the ETC will lead to the depolarisation of the MMP and inhibition of ATP production. The cell death that follows from this mitochondrial dysregulation will give rise to the elevated ROS seen after 4 hours or at higher ATO concentration (Figure 3C and 3D) as reported by others [46] after ATO treatment. Thus elevated ROS is a consequence, not the cause, of ATO induced cell death.

The previously proposed mitochondrial target for ATO is the MTP. Zheng et al demonstrated that ATO induces the opening of the MTP in isolated rat liver mitochondria [11], leading to the proposal that MTP is responsible for the release of ROS and the depolarization of the MMP seen during arsenic treatment, and subsequent apoptosis [47]. Our study does not exclude MTP as a target for ATO. Our data indicate that inhibition of the MTP via CsA and BA can partially block caspase $3 / 7$ activation induced by high concentration ATO, however the MTP blockers failed to inhibit the depolarization of MMP and the reduction in ROS and ATP levels caused by low concentration ATO. Thus although ATO can open the MTP, alternative targets are required to explain the action of ATO at low concentrations. Inhibition of the thioredoxin system has been shown to occur in MCF-7 cells after treatment with 2-5 $\mu \mathrm{M}$ ATO and may mediate some cellular effects of ATO at low concentrations [13], however this mechanism would lead to increased oxidative stress, and cannot explain the decreased ROS observed in the current study.

DCA, as a pyruvate dehydrogenase kinase inhibitor, can reverse the glycolytic effect and has demonstrated significant anti-cancer properties both in vitro and in vivo [17-23]. Some studies show increased apoptosis with DCA $[17,18,20]$. However our studies in breast cancer and studies by Stockwin et al indicate that DCA acts as a cytostatic rather than cytotoxic agent across a range of cell lines except at very high concentrations $[22,48]$. Michelakis recently reported trough serum levels of DCA to be 0.5 $\mathrm{mM}$ in glioblastoma patients taking $6.25 \mathrm{mg} / \mathrm{kg}$ orally twice daily [23], thus the clinically relevant concentrations are likely to be in the range of $0.5-5 \mathrm{mM}$. DCA has been shown to induce a small but significant increase in caspase $3 / 7$ activity even when apoptosis was not observed and it was proposed that DCA may sensitize cancer cells towards cytotoxic agents [22]. The current study confirmed this hypothesis by showing that DCA sensitized T-47D cells towards ATO treatment as seen from AV+/PI+ double staining (Figure 1E and text). ATO was selected as the agent for testing due to its anti-mitochondrial properties, as we proposed that by reversing the glycolytic phenotype with DCA, and directing more pyruvate into mitochondrial oxidative phosphorylation, while simultaneously targeting the mitochondria with ATO, a cooperative effect would be seen with this drug combination. The principle of this dual targeting strategy is supported by the results of two recent publications which found that cells with 
mitochondrial defects (e.g. rho (0) or after treatment with non-drug mitochondrial inhibitors such as rotenone) show higher sensitivity to the growth inhibition effects of DCA $[48,49]$. While the efficacy of this dual targeting strategy is yet to be demonstrated in vivo, the ATO/DCA enhanced combination effects were seen on both growth inhibition and apoptosis at drug concentrations in clinically relevant ranges. Some effects at the lower end of the concentration range were not large (eg. 15\% increase in apoptotic cells), however the impact in vivo over weeks rather than hours of treatment warrants further investigation.

It has been well documented that DCA can alter mitochondrial behavior i.e. depolarize the MMP $[18,20]$. However this phenomenon has not been well explained. We observed that DCA can increase ATP while depolarizing MMP in T-47D cells (Figure 2). Based on these data we proposed that DCA is altering mitochondrial function through complex $\mathrm{V}$ of the ETC, ATP synthase. ATP synthase is the last step of the ETC and it uses the MMP generated by the ETC to produce ATP. ATP $\beta$ is downregulated in lung, brain, breast and gastric cancers [50], which could explain the hyperpolarized mitochondrial membrane that can be found in many cancer cells [51]. We have hypothesized that DCA can increase ATP synthase activity either via allosteric regulation due to its homology to pyruvate or via increase in ATP synthase protein levels after the reversal of the Warburg effect and decreased HIF-1 $\alpha$ levels. Immunoblotting clearly demonstrated that ATP $\beta$ is up-regulated after DCA treatment (Figure 7D) suggesting that DCA can increase ATP synthase activity, which in turn contributes to increased ATP production and exhaustion of the MMP.

HIF- $1 \alpha$ and c-Myc are two major oncogenic transcription factors known to regulate metabolism in cancer cells. HIF-1 $\alpha$ can up regulate the enzymes of the glycolytic pathway and lactic acid dehydrogenase, sustaining the Warburg effect in cancer cells [33]. This not only increases ATP production, but also increases the supply of precursors such as glucose-6-phophate and fructose-6-phosphate for the production nucleic acids through the pentose phosphate pathway [16]. c-Myc, on the other hand, not only plays a central role in promoting $\mathrm{G} 1$ to $\mathrm{S}$ phase cell cycle transition by regulating the cyclins and their kinases and inhibitors, but also up regulates protein components of the ETC such as COXI-IV and helps to increase mitochondrial activity [52]. Thus, the combination of c-Myc and HIF-1 $\alpha$ overexpression is important for inducing the Warburg effect while increasing mitochondrial activity, supporting the glutamine-TCA hub that is essential for anabolism of amino acids and fatty acids needed for cell division [16]. This metabolic signature contributes to carcinogenesis and the malignant phenotype of many tumors $[33,34]$. Both ATO and DCA can decrease HIF-1 $\alpha$ levels significantly suggesting a reduction in the Warburg effect
(Figure 7C). While DCA alone had no effect on c-Myc levels, surprisingly, ATO up regulated c-Myc levels significantly (Figure 7B). This may be a positive feed back loop, where the cells are trying to increase ETC activity after the inhibition of complex IV. Strikingly, DCA reversed the effect of ATO on c-Myc, and the combination of ATO/ DCA strongly repressed c-Myc expression, correlating with the ability of these agents to work together at reducing cell proliferation and inducing cell death (Figure 1).

The efficacy of ATO against PML has been attributed to several special features of this malignancy - differentiation through inactivation of PML-RAR $\alpha$, low antioxidant capacity of PML cells to protect against the elevated ROS levels, and accumulation of the drug due to impaired osmoregulation [5]. Many trials are underway for the use of ATO in a range of solid malignancies, although thus far there are few results published. Results that are available suggest that ATO is not highly effective as a single agent in patients with advanced cancer of the pancreas, liver or melanoma [5]. Investigators are advocating evaluating ATO in combination with other anticancer drugs $[53,54]$ with some phase I trials being completed [55]. As our understanding of the mechanisms of ATO continues to grow, especially its effects through cancer metabolism, we may be better able to harness its anticancer potential in vivo in novel drug combinations.

\section{Conclusions}

Two recent reports found DCA to be most effective against cells with mitochondrial defects $[48,49]$. This report is the first to demonstrate that targeting of two aspects of metabolism - reversing of the Warburg effect with DCA while inhibiting oxidative phosphorylation with ATO - is clearly an effective anti-cancer strategy in vitro against breast cancer cell lines. The identification of cytochrome $\mathrm{C}$ oxidase as a mitochondrial target for ATO provides novel mechanistic information for the application of ATO to the treatment of tumor types other than APL. The ability of DCA to increase ATP synthase $\beta$ subunit expression, reversing another widespread cancer metabolic phenotype, also suggests DCA may be relevant to a broad range of tumor types. The ability of DCA to enhance the cytotoxic effects of chemotherapeutic agents other than ATO in vitro and in vivo is also worthy of further investigation. The lack of sensitivity of the noncancerous cell line MCF-10A to the clinically relevant concentrations of ATO/DCA tested is also encouraging, and suggests that this treatment strategy should be further tested against solid tumors in vivo.

\section{List of abbreviations}

APL: acute promyeloid leukemia; ATO: arsenic trioxide; ATP $\beta$ : ATP synthase $\beta$ subunit; AV: annexin V; BA: bongkrekic acid; CFSE: carboxyfluorescein succinimidyl ester; CsA: cyclosporine A; DCA: dichloroacetate; ETC: electron 
transport chain; $\mathrm{H}_{2}$ DCFDA: 2', 7'-dihydrochlorofluroresceinacetate; JC-1: 5,5',6,6'-tetrachloro-1,1', 3,3'-tetraethylbenzimidazol-carbocyanine iodide; MMP: mitochondrial membrane potential; MTP: mitochondrial transition pore; NaCN: sodium cyanide; PI: propidium iodide; ROS: Reactive oxygen species; TTFA: thenolytrifluoroacetone.

\section{Acknowledgements}

This research was supported by a grant from the National Breast Cancer Foundation Australia (AB), and by NHMRC 366787 R.D. Wright Career Development Award (AB). PB is supported by NHRMC and Australian National University. RS was supported by an Australian National University Postgraduate scholarship.

\section{Author details}

${ }^{1}$ Molecular Genetics Group, Department of Translational Biosciences, John Curtin School of Medical Research, Building 131, Australian National University, P.O. Box 334, Canberra ACT 0200, AUSTRALIA. ${ }^{2}$ Department of Radiation Oncology, Stanford School of Medicine, Stanford CA 94305 USA.

\section{Authors' contributions}

RS designed and carried out the experiments, and drafted the manuscript. PB participated in the analysis of data and manuscript preparation. $A B$ participated in the design and analysis of the data, and prepared the manuscript for publication. All authors have read and approved the final manuscript.

\section{Competing interests}

The authors declare that they have no competing interests.

Received: 3 May 2011 Accepted: 18 November 2011

Published: 18 November 2011

\section{References}

1. Antman KH: Introduction: the history of arsenic trioxide in cancer therapy. Oncologist 2001, 6(Suppl 2):1-2.

2. Emadi A, Gore SD: Arsenic trioxide - An old drug rediscovered. Blood Rev 2010, 24:191-199.

3. Powell BL, Moser B, Stock W, Gallagher RE, Willman CL, Stone RM, Rowe JM, Coutre S, Feusner JH, Gregory J, et al: Arsenic trioxide improves event-free and overall survival for adults with acute promyelocytic leukemia: North American Leukemia Intergroup Study C9710. Blood 2010, 116:3751-3757.

4. Wang ZY, Chen Z: Acute promyelocytic leukemia: from highly fatal to highly curable. Blood 2008, 111:2505-2515.

5. Dilda PJ, Hogg PJ: Arsenical-based cancer drugs. Cancer Treat Rev 2007, 33:542-564.

6. Chen GQ, Zhu J, Shi XG, Ni JH, Zhong HJ, Si GY, Jin XL, Tang W, Li XS, Xong SM, et al: In vitro studies on cellular and molecular mechanisms of arsenic trioxide (As203) in the treatment of acute promyelocytic leukemia: As203 induces NB4 cell apoptosis with downregulation of Bcl2 expression and modulation of PML-RAR alpha/PML proteins. 1996, 88:1052-1061.

7. Kanzawa T, Kondo Y, Ito H, Kondo S, Germano I: Induction of autophagic cell death in malignant glioma cells by arsenic trioxide. Cancer Res 2003, 63:2103-2108.

8. Nakagawa Y, Akao Y, Morikawa H, Hirata I, Katsu K, Naoe T, Ohishi N, Yagi K: Arsenic trioxide-induced apoptosis through oxidative stress in cells of colon cancer cell lines. Life Sciences 2002, 70:2253-2269.

9. Ralph SJ: Arsenic-based antineoplastic drugs and their mechanisms of action. Met Based Drugs 2008, 2008:260146.

10. Cai X, Shen YL, Zhu Q, Jia PM, Yu Y, Zhou L, Huang Y, Zhang JW, Xiong SM, Chen SJ, et al: Arsenic trioxide-induced apoptosis and differentiation are associated respectively with mitochondrial transmembrane potential collapse and retinoic acid signaling pathways in acute promyelocytic leukemia. Leukemia 2000, 14:262-270.

11. Zheng Y, Shi Y, Tian C, Jiang C, Jin H, Chen J, Almasan A, Tang H, Chen Q: Essential role of the voltage-dependent anion channel (VDAC) in mitochondrial permeability transition pore opening and cytochrome $c$ release induced by arsenic trioxide. Oncogene 2004, 23:1239-1247.

12. Tian X, Ma X, Qiao D, Ma A, Yan F, Huang X: $m$ CICR is required for As2O3induced permeability transition pore opening and cytochrome $\mathrm{c}$ release from mitochondria. Mol Cell Biochem 2005, 277:33-42.
13. Lu J, Chew EH, Holmgren A: Targeting thioredoxin reductase is a basis for cancer therapy by arsenic trioxide. Proc Natl Acad Sci USA 2007, 104:12288-12293.

14. Kim JW, Dang CV: Cancer's molecular sweet tooth and the Warburg effect. Cancer Res 2006, 66:8927-8930.

15. Warburg O, Wind F, Negelein E: Ueber den Stoffwechsel von Tumoren im körper. Klinische Wochenschrift 1926, 5:829-832.

16. DeBerardinis RJ, Mancuso A, Daikhin E, Nissim I, Yudkoff M, Wehrli S, Thompson CB: Beyond aerobic glycolysis: Transformed cells can engage in glutamine metabolism that exceeds the requirement for protein and nucleotide synthesis. Proc Natl Acad Sci 2007, 104:19345-19350.

17. Wong JY, Huggins GS, Debidda M, Munshi NC, De Vivo I: Dichloroacetate induces apoptosis in endometrial cancer cells. Gynecol Oncol 2008, 109:394-402.

18. Cao W, Yacoub S, Shiverick KT, Namiki K, Sakai Y, Porvasnik S, Urbanek C, Rosser CJ: Dichloroacetate (DCA) sensitizes both wild-type and over expressing Bcl-2 prostate cancer cells in vitro to radiation. Prostate 2008, 68:1223-1231

19. Papandreou I, Goliasova T, Denko NC: Anticancer drugs that target metabolism: Is dichloroacetate the new paradigm? Int J Cancer 2011, 128:1001-1008.

20. Bonnet S, Archer SL, Allalunis-Turner J, Haromy A, Beaulieu C, Thompson R, Lee $C T$, Lopaschuk GD, Puttagunta L, Bonnet $S$, et al: A mitochondria-K+ channel axis is suppressed in cancer and its normalization promotes apoptosis and inhibits cancer growth. Cancer Cell 2007, 11:37-51.

21. Chen Y, Cairns R, Papandreou I, Koong A, Denko NC: Oxygen consumption can regulate the growth of tumors, a new perspective on the Warburg effect. PLoS One 2009, 4:e7033.

22. Sun RC, Fadia M, Dahlstrom JE, Parish CR, Board PG, Blackburn AC: Reversal of the glycolytic phenotype by dichloroacetate inhibits metastatic breast cancer cell growth in vitro and in vivo. Breast Cancer Res Treat 2010, 120:253-260.

23. Michelakis ED, Sutendra G, Dromparis P, Webster L, Haromy A, Niven E, Maguire C, Gammer TL, Mackey JR, Fulton D, et al: Metabolic modulation of glioblastoma with dichloroacetate. Sci Transl Med 2010, 2:31 ra34.

24. Chrzanowska-Lightowlers ZMA, Turnbull DM, Lightowlers RN: A microtiter plate assay for cytochrome $\mathrm{c}$ oxidase in permeabilized whole cells. Analytical Biochemistry 1993, 214:45-49.

25. Theodoratos A, Tu WJ, Cappello J, Blackburn AC, Matthaei K, Board PG: Phenylalanine-induced leucopenia in genetic and dichloroacetic acid generated deficiency of glutathione transferase Zeta. Biochem Pharmacol 2009, 77:1358-1363.

26. Shen $Z X$, Chen GQ, Ni JH, Li XS, Xiong SM, Qiu QY, Zhu J, Tang W, Sun GL, Yang KQ, et al: Use of arsenic trioxide (As2O3) in the treatment of acute promyelocytic leukemia (APL): II. Clinical efficacy and pharmacokinetics in relapsed patients. Blood 1997, 89:3354-3360.

27. Maeda H, Hori S, Nishitoh H, Ichijo H, Ogawa O, Kakehi Y, Kakizuka A: Tumor Growth Inhibition by Arsenic Trioxide (As2O3) in the Orthotopic Metastasis Model of Androgen-independent Prostate Cancer. Cancer Res 2001, 61: 5432-5440.

28. Samikkannu T, Chen CH, Yih LH, Wang AS, Lin SY, Chen TC, Jan KY: Reactive oxygen species are involved in arsenic trioxide inhibition of pyruvate dehydrogenase activity. Chem Res Toxicol 2003, 16:409-414.

29. Campbell MK, Farrell SO: Biochemistry. 4 edition. Thomson learning, Inc.; 2003.

30. Liu Y, Fiskum G, Schubert D: Generation of reactive oxygen species by the mitochondrial electron transport chain. J Neurochem 2002, 80:780-787.

31. Larochette N, Decaudin D, Jacotot E, Brenner C, Marzo I, Susin SA Zamzami N, Xie Z, Reed J, Kroemer G: Arsenite induces apoptosis via a direct effect on the mitochondrial permeability transition pore. Exp Cell Res 1999, 249:413-421.

32. Marzo I, Brenner C, Zamzami N, Jurgensmeier JM, Susin SA, Vieira HL, Prevost MC, Xie Z, Matsuyama S, Reed JC, Kroemer G: Bax and adenine nucleotide translocator cooperate in the mitochondrial control of apoptosis. Science 1998, 281:2027-2031.

33. Semenza GL: Regulation of cancer cell metabolism by hypoxia-inducible factor 1. Semin Cancer Biol 2009, 19:12-16.

34. Dang CV, O'Donnell KA, Zeller KI, Nguyen T, Osthus RC, Li F: The c-Myc target gene network. Seminars in Cancer Biology 2006, 16:253-264. 
35. Yang J, Liu X, Bhalla K, Kim CN, Ibrado AM, Cai J, Peng TI, Jones DP, Wang $\mathrm{X}$ : Prevention of apoptosis by $\mathrm{Bcl}-2$ : Release of cytochrome $\mathrm{c}$ from mitochondria blocked. Science 1997, 275:1129-1132.

36. Carney DA: Arsenic trioxide mechanisms of action-looking beyond acute promyelocytic leukemia. Leuk Lymphoma 2008, 49:1846-1851.

37. Kito M, Matsumoto K, Wada N, Sera K, Futatsugawa S, Naoe T, Nozawa Y, Akao Y: Antitumor effect of arsenic trioxide in murine xenograft model. Cancer Sci 2003, 94:1010-1014.

38. Xu HY, Yang YL, Liu SM, Bi L, Chen SX: Effect of arsenic trioxide on human hepatocarcinoma in nude mice. World J Gastroenterol 2004, 10:3677-3679.

39. Tsukihara T, Aoyama H, Yamashita E, Tomizaki T, Yamaguchi H, ShinzawaItoh K, Nakashima R, Yaono R, Yoshikawa S: The whole structure of the 13subunit oxidized cytochrome c oxidase at 2.8 A. Science 1996, 272:1136-1144.

40. Pelicano H, Carney D, Huang P: ROS stress in cancer cells and therapeutic implications. Drug Resist Updat 2004, 7:97-110.

41. Kamata $\mathrm{H}$, Hirata $\mathrm{H}$ : Redox regulation of cellular signalling. Cellular Signalling 1999, 11:1-14.

42. Hayes JD, McLellan LI: Glutathione and glutathione-dependent enzymes represent a co-ordinately regulated defence against oxidative stress. Free Radic Res 1999, 31:273-300.

43. Nordberg J, Arner ESJ: Reactive oxygen species, antioxidants, and the mammalian thioredoxin system. Free Radical Biology and Medicine 2001, 31:1287-1312.

44. Yao LL, Wang YG, Cai WJ, Yao T, Zhu YC: Survivin mediates the antiapoptotic effect of $\delta$-opioid receptor stimulation in cardiomyocytes. Journal of Cell Science 2007, 120:895-907.

45. Martindale $J$, Holbrook NJ: Cellular response to oxidative stress: Signaling for suicide and survival. J Cell Physiol 2002, 192:1-15.

46. Perkins C, Kim CN, Fang G, Bhalla KN: Arsenic induces apoptosis of multidrug-resistant human myeloid leukemia cells that express Bcr-Abl or overexpress MDR, MRP, Bcl-2, or Bcl-x(L). Blood 2000, 95:1014-1022.

47. Ma XD, Qiao DF, Tian XM, Yan F, Ma AD: Mechanism of opening of mitochondrial permeability transition pore induced by arsenic trioxide. Ai Zheng 2006, 25:17-21.

48. Stockwin LH, Yu SX, Borgel S, Hancock C, Wolfe TL, Phillips LR, Hollingshead MG, Newton DL: Sodium Dichloroacetate (DCA) selectively targets cells with defects in the mitochondrial ETC. Int J Cancer 2010.

49. Sanchez-Arago M, Chamorro M, Cuezva JM: Selection of cancer cells with repressed mitochondria triggers colon cancer progression. Carcinogenesis 2010, 31:567-576.

50. Isidoro A, Martinez M, Fernandez PL, Ortega AD, Santamaria G, Chamorro M, Reed JC, Cuezva JM: Alteration of the bioenergetic phenotype of mitochondria is a hallmark of breast, gastric, lung and oesophageal cancer. Biochemical Journal 2004, 378:17-20.

51. Susin SA, Zamzami N, Kroemer G: Mitochondria as regulators of apoptosis: Doubt no more. Biochimica et Biophysica Acta - Bioenergetics 1998, 1366:151-165.

52. Shim H, Dolde C, Lewis BC, Wu CS, Dang G, Jungmann RA, Dalla-Favera R, Dang CV: c-Myc transactivation of LDH-A: Implications for tumor metabolism and growth. Proc Natl Acad Sci USA 1997, 94:6658-6663.

53. Kim KB, Bedikian AY, Camacho LH, Papadopoulos NE, McCullough C: A phase II trial of arsenic trioxide in patients with metastatic melanoma. Cancer 2005, 104:1687-1692.

54. Subbarayan PR, Lima M, Ardalan B: Arsenic trioxide/ascorbic acid therapy in patients with refractory metastatic colorectal carcinoma: a clinical experience. Acta Oncol 2007, 46:557-561.

55. Ardalan B, Subbarayan PR, Ramos Y, Gonzalez M, Fernandez A, Mezentsev D, Reis I, Duncan R, Podolsky L, Lee K, et al: A phase I study of 5 -fluorouracil/leucovorin and arsenic trioxide for patients with refractory/relapsed colorectal carcinoma. Clin Cancer Res 2010, 16:3019-3027

\section{doi:10.1186/1476-4598-10-142}

Cite this article as: Sun et al:: Targeting metabolism with arsenic trioxide and dichloroacetate in breast cancer cells. Molecular Cancer 2011 10:142.

\section{Submit your next manuscript to BioMed Central and take full advantage of:}

- Convenient online submission

- Thorough peer review

- No space constraints or color figure charges

- Immediate publication on acceptance

- Inclusion in PubMed, CAS, Scopus and Google Scholar

- Research which is freely available for redistribution

Submit your manuscript at www.biomedcentral.com/submit
Biomed Central 